\title{
Energy Growth and Sustainable Development (Need for Reform Policies)
}

\author{
Dummu Tata Rao \\ Dept. of Rural Development, Dr. B. R. Ambedkar University, Srikakulam, Etcherla, Andhra Pradesh, India
}

\section{Email address:}

tatagiphd@yahoo.com

\section{To cite this article:}

Dummu Tata Rao. Energy Growth and Sustainable Development (Need for Reform Policies). International Journal of Genetics and Genomics. Vol. 3, No. 3, 2015, pp. 32-35. doi: 10.11648/j.ijgg.20150303.12

\begin{abstract}
The farmers have been facing problems. They are maintaining to mostly food grains and also fiber. And other hand, this increased production will depend on natural resources. Mostly land is converted to fertile land to non-agricultural purposes. The land degradation from erosion, water logging, mining and Stalinization etc. The increasing agricultural production is most difficult in Asia where cropping intensity is already highest in the developing world. The yield increase is limited by poor agricultural practices that result in unsustainable family systems. The adoption of modern farming system is forwarded. The millions of the poor people need access to updated new modern technology. The rural people are being depended on multitraditional innovative ideas.
\end{abstract}

Keywords: Energy Growth, Sustainable Development and Natural Resources

\section{Introduction}

Today some 1.6 billion people lack access to electricity and around 2.4 billion use traditional biomass such as wood or dung for cooking. How should energy production and distribution in low income and lower-middle income countries be guided. Owned and regulated in order to achieve development objectives on economic growth, environment, climate, equity and human rights. Vast areas of fertile land are being converted to non-agricultural uses and what remains is threatened by degradation from erosion, nutrient mining, water logging and Stalinization. Given this situation, "the challenge of increasing agricultural production is even more difficult in Asia where cropping intensity are already highest in the developing world. The potential for yield increases is further limited by poor agricultural resource management practices that result in unsustainable farming systems" (Nath, 1999). Are there any solutions to these problems? Many argue that widespread adoption of modern technological farming options offers the best way forward. FAO notes that "Millions of poor rural people desperately need access to updated technologies, including machines, improved plant varieties and animal breeds, better crop and post-harvest techniques, and higher investment. Seeing subsistence farming as a "traditional way of life" is part of a "rural nostalgic atavism that is out of step with reality" (FAO, 2000).
Unfortunately, farmers around the world have been slow to adopt sustainable agricultural practices. As Pretty (1995) states, "although there exists successful applications of sustainable agriculture throughout the world, very few farmers have adopted both the technologies and the practices. Numerous reasons have been postulated to explain this situation. One is that poor small farmers are, by necessity, risk averse. As Reeves (2000) notes, "The concept of sustainable agriculture is difficult to deal with in most countries, particularly in many developing countries, where farmers have few resources and little flexibility to change their practices, and where the risks of failure often have tragic consequences." Sustainable development, including the preservation of the environment and the conservation of natural resources, is, without exception, a concern of every nation in the world. These challenges will require: a broadbased approach to "agricultural education"; innovative leadership including a greater involvement of the private sector and institutional partnerships; and new educational strategies such as a greater application of distance learning and community development initiatives. (Lindley, 1998).

The greatest challenge of today is the improvement in the quality of human life particularly of the rural people through eradication of poverty and hunger and overall achieving rural - urban balance. Agriculture being the pivotal sector of rural economy in India, the empowerment of the farmers in taking initiatives and decisions will help in shaping the future of the 
farmers' economy. The challenge of eradicating poverty and hunger is essentially a problem of low income rather than a problem of low production and productivity only. The majority of world's I billion poor live in the rural areas of the developing countries, who are mostly small-scale farmers. At present, there are 2.4 billion people working in agriculture representing 45 per cent of the world population. Farmers as producers of food must have an enabling environment for access to know-how and do-how for realizing the full potential of modern agricultural technology. The modern agricultural technology, however, depends much on energy resources and the energy growth leads to sustainable development.

\section{Energy Trends in India}

The economy of India is booming and its increasing energy demand is not only transforming the world's energy markets but also changing the geo political setting. India was the fifth largest consumer of oil in the world during 2006 according to Energy Information Agency (EIA 2007). The Indian government estimates that the country's energy consumption will rise to 50 per cent by 2015 based on 2005 levels. Similarly to China, reliable energy supply has become a limiting factor for the future development of India's economy, both for its emerging industry as for the country's rural development. India's domestic coal reserve reaches 101,903 million tons with an annual production of over 400 million tons. While some coal is still being imported from Australia, Indonesia and South Africa, vast majority of the domestic demand is met with domestic production (EIA 2007). In 2004, India's estimated domestic coal consumption was 478.2 million tons, among which 443.7 million tons were supplied domestically. However, India, like China, faces sharp rise in oil consumption despite stagnant oil production levels. As a result, 70 per cent of the oil consumed in India must be imported, mainly from the Middle East. The IEA foresees that by 2030 oil imports will rise to 90 per cent and gas imports to 40 per cent to meet India's energy demand.

India still has one of the lowest $\mathrm{CO} 2$ emission levels per capita. The Indian government has therefore steadfastly opposed any binding reduction commitments in the ongoing negotiations for a post-Kyoto climate regime. However, India has a developed renewable energy sector, based both on traditional and modern technologies. India's wind power industry is one of the world's technological leaders. India is one of the top five wind energy generating countries along with Germany, the United States, Denmark, and Spain (Herbert et. al. 2006). India relies mainly on the international engagement of its private energy sector. Other than China's national oil companies and European or US based multinationals, India's private energy companies are seriously undercapitalized. India could access international development funding for regional energy development projects, however not for the international expansion of its energy companies. This has led to a close cooperation with
Chinese efforts in Africa and Southeast Asia. Recently, the government has also started to back up the international engagement of its private energy companies with public diplomacy, although without the financial incentives that the Chinese provide to resource rich clients. India signed a far reaching energy cooperation agreement with the US in 2005 (Chipaux 2006). The agreement still has to be ratified by both countries' parliaments and has therefore not yet entered into force. It contains provisions for technology cooperation and, most prominently, in the area of nuclear technology.

\section{India's Energy Diplomacy}

Since the cold war is over, India has emerged as a regional hegemony but with no recognizable strategy beyond the shores of the sub-continent. India's supreme foreign policy objective has always been to isolate neighboring Pakistan. Energy security considerations are however emerging as a second theme of Indian diplomacy. Over the last decade, India did support anti-Taliban fighters in Afghanistan to gain political influence in a country that could serve as a bridge to energy rich Central Asia. Although India is negotiating a far reaching energy agreement with the US, parallel negotiations with Iran to build new oil and gas export lines, are being advanced. India plans to expand the use of nuclear power for electricity production. Until recently, access to nuclear fuel has been the limiting factor for India's nuclear power program. After having tested nuclear weapons in the early Nineties, India and Pakistan were both put under an international embargo that did not allow either country to import nuclear technology and fuels from the influential "nuclear suppliers group".

India wants to expand its access to investment in Russia's vast oil reserves (New York Times 2007). Reliance Industries, an Indian energy company, has floated the idea of investing in a Russian refinery. According to Indian officials, Russia has also expressed an interest in investing in a pipeline that would carry natural gas from Iran through Pakistan to India. The Bush administration has repeatedly expressed reservations about the project. Far more important, analysts pointed out, Moscow is already New Delhi's largest defense partner. Paradoxically, when the India-United States nuclear deal opens the door for New Delhi to buy nuclear technology to expand its civilian nuclear program, Russia may benefit. India would be allowed to purchase nuclear fuel, reactors and other technology on the world market, but only after it gained approval from the 45-nation Nuclear Suppliers Group, which regulates international atomic energy trade. The waste-to-energy industry is trying to relocate itself in India and China taking advantage of tax regulations and low awareness of the hazards of incineration.

The Prime Minister Manmohan Singh's pledge to double India's renewable energy capacity by 2017 . Renewable energy sources have a key role to play in the transition towards a sustainable and low-carbon economy worldwide. Some technologies that are being pitched in the guise of renewable energy have the potential to cause even more 
harm than fossil fuel based energy sources. The United states Environmental Protection Agency (USEPA), the foremost environmental agency in the U.S., recognizes that incinerators emit 2.5 times more carbon dioxide per MW than coal fired power plants. The generating energy incinerators are very expensive and inefficient, their financial viability relies heavily on various fiscal and financial incentives from government such as capital subsidies, concessional customs duties on the import of machinery and components excise duty exemptions, relief of taxes, etc.

According to the U.S. Energy Information Administration's Annual Energy Outlook 2010, the projected capital cost of new waste incinerator facilities is $\$ 8,232$ per kilowatt hour. It is twice the cost of coal-fired power and 60 per cent more than advanced nuclear energy. Despite this, the government is still determined to pursue Waste-to-energy (WtE) as a solution and has decided to divert huge amount of public money to subsidize the WtE industry. In the Twelfth Five Year Plan (2012-2017), what the MNRE envisage includes substantial investments in WtE.

\section{Global Challenges}

European governments have advocated a paradigm shift of international energy financing from major oil, gas or hydropower projects to renewable energies and energy efficiency. This shift will only happen if the main customers of the World Bank and other regional development banks go along with it. A reorientation of international energy lending can only take place if Chinese lending in Africa or Brazilian lending in South America do not compete with such a new approach towards sustainable development. The Organization for Economic Cooperation and Development (OECD) and its sister organization, the IEA have carefully moved to include new members, as most recently Mexico and South Korea. Since 2006, the OECD is being led by a Mexican national who has announced to open the organization to newly emerging economies. However, at the recent G8 summit, the leaders of the dominating economies mandated the OECD only to open a dialogue process with those emerging economies rather than starting a process towards full membership. Both the OECD and the IEA already collect numerous data about China and India. The sister organizations run offices in both countries, provide their analytical capabilities and give advice for economic reform. Their data on energy production and consumption are widely used and relied upon. However, full participation in OECD/IEA remains elusive as long as Western governments do not want to share their influence on those organizations.

The exclusion of the emerging economies from the informal but influential club of the G8 itself is highly symbolic. The G8 have stopped to represent the world's major economies. Such a forum would have to include China and maybe India or Brazil. The current arrangement of informal "G8+5" arrangements, or ad hoc invitations of additional countries to the summit's deliberations, does neither produce results nor enjoy legitimacy. The Heiligendamm G8 summit in June 2007 might have been the last occasion when China, India and other representatives of emerging powers were willing to wait in the anteroom and listen to pre-conceived results of the big 8's deliberations. (G8 Summit, Heiligendamm 2007).

The global arena has yet to adjust to the shift in balance of power away from the West to the East with the growing emergence of Asian nations, primarily of China and India. As the unique and successful example of an integrated regional community and power, the EU has much wisdom to share with other members of the global community and much to contribute in the construction of a new world order. China's role in international organizations is growing and can only continue to grow as the world anticipates China to replace Japan as the world's second largest economy. In the WTO, China has developed into the most prominent player next to the EU and the US. China is an active member in the Association of Southeast Asian Nations (ASEAN+3) and the Asia-Pacific Economic Cooperation (APEC). China's currency, the Yuan, plays a growing role in both Asia's and the global currency system. The Chinese government can influence the system significantly by controlling exchange rates and by the mere fact that it holds a significant part of the US national debt. China's active participation is also anticipated and needed in a number of significant international treaties as the Kyoto Protocol on climate change. Given the importance of China's potential impact in the global arena, it is in the EU's interest to actively involve China as a responsible stakeholder. Ultimately, it is in the EU's best interest as a global power to coordinate a cohesive EU-China policy in conjunction with its transatlantic policy and thereby contribute to the global balance of power.

Both China and the EU depend on energy imports from Russia. This dependency is projected to grow when other sources of oil and gas imports run dry and when all lanned infrastructure projects with Russia are being implemented. On their summit meeting in September 2006, China and the EU signed a common declaration on energy security that mirrors the agreed principles of the G8 summit in St. Petersburg. Both sides want to cooperate on new energy technologies, most notably renewable energies and CCS, as well as in the creation of common markets. In principle, the European Union would be China's partner of choice on the international scene. Without posing a security threat to China, The EU carries enough economic and political weight to counter balance US and Russian influence in the region. In the past decade, Europe's interest has mainly focused on building a strategic relationship with emerging China. However, India and other South and East Asian countries should not be forgotten when the EU develops a new "Eastern policy".

\section{Conclusion}

The Indian Economy is increasing at an unprecedented pace, due to high economic growth based on new 
technological farming and rapid industrialization. The energy consumption of the India is increasing fast. In India, new foreign policies for energy were established, which is transforms the existing geopolitical rivalries is emerging. The European Union must react to these developments when shaping their policy response. The International institutions and governance structures have to adapt to take an account the growing the India and other countries. The climate change considerations should be merged into an integrated energy policy. The sustainability means the basic needs of the present generation and fills their own needs of future generations.

\section{References}

[1] Chipaux, F. (2006): Le dilemma nucleaire indien, in: Le Monde 2 March 2006.

[2] EIA (Energy Information Agency) (2007): Country Analysis Briefs India, January 2007; online: http//www.eia.doe.gov/emeu/cabs/India/Full.html.

[3] FAO (2001) Renewing SARD: Further progress toward sustainable agriculture and rural development requires a radical shift in priorities towards alleviating poverty and social exclusion. In Agriculture 21, March. [Online] A available: http://www.fao.org/ag/magazine/0103 sp 3.htm.
[4] G8 Summit Heiligendamm (2007): Growth and responsibility in the World Economy: Summit Declaration, 07 June 2007.

[5] Herbert, G. et al. (2006): Prospcts of wind energy in India, in: International Journal of Global Energy Issues 26 (2-4), 258287.

[6] Lindley, W.I. (1998) The Relevance of Higher Education in Agriculture and Rural Development. Speech delivered at World Conference on Higher Education; Higher Education in the Twenty-first Century; Vision and Action. UNESCO, Paris, $5-9$ October. [Online] Available: http://unesdoc.unesco.org/images/001170/117075e.pdf

[7] Nath, P. (1999) Economic Parameters for small Holders. In: Proceeding of Food for the Billions: Sustainable Agriculture the Global Issue, Asia Pacific Crop Protection Association, Bangkok, Thailand.

[8] New York Times (2007): Putin in India: Visit is Sign of Durability of Old Times, 25 Jan., 2007.

[9] Pretty, J.N. (1995). Regenerating Agriculture: Policies and Practice for Sustainability and Self-Reliance, London, England: Earthscan Publications, 320.

[10] Reeves, T. (1998) Sustainable Intensification of Agriculture. CIMMYT. Apdo. Postal 6-641, 06600 Mexico, D.F., Mexico. [Online] http://www.cimmyt.cgiar.org/whatiscimmyt/SustInt.htm 